\title{
ASSESSING COMPLIANCE OF CONSERVATION SUSTAINABLE PRODUCTION STANDARDS AND PROFIT EFFICIENCY IN SMALL-SIZED FARMS IN KENYA
}

\author{
GICHUKI, C. N. ${ }^{1}-$ HAN, J. ${ }^{1 *}-$ QIANG, L. ${ }^{1}-$ NJAGI, T. ${ }^{2}-$ NJINJU, S. M. ${ }^{3}$ \\ ${ }^{1}$ College of Economics and Management Nanjing Agricultural University, Nanjing, China \\ (e-mail: ngumbucg@gmail.com (Gichuki, C. N.); nideliuqiang@163.com (Qiang, L.)) \\ ${ }^{2}$ Tegemeo Institute of Agricultural Policy and Development, Egerton University, Nairobi, Kenya \\ (e-mail:tnjagi@tegemeo.org) \\ ${ }^{3}$ Kenya Agricultural and Livestock Research Organization, Nairobi, Kenya \\ (e-mail:mugosimon7@yahoo.co.uk) \\ Corresponding author \\ e-mail: jhan@njau.edu.cn; phone: +1-3815-875-653 \\ (Received 20 $0^{\text {th }}$ Dec 2018; accepted $10^{\text {th }}$ Apr 2019)
}

\begin{abstract}
Sustainable Conservation Standards (SCS) promote the need for preserving soil life system and minimal use of farm chemicals including fertilizer to replenish the soil. The standards also guide farmers to meet international food safety and production standards such as Global Good Agricultural Practices (GLOBALGAP). The study was conducted in Kenya examined and compared levels of compliance to Sustainable Conservation Standards between GLOBALGAP certified and Non-GLOBALGAP Certified farms. Also, the study examined profit efficiency between GLOBALGAP certified and Non-GLOBALGAP Certified farms. The sample size comprised of 429 randomly selected smallholder farmers from three major snap bean producing regions in Kenya. The result revealed that the majority of GLOBALGAP certified farmers were likely to comply to Sustainable Conservation Standards techniques such as low usage of pesticides, herbicides, and fertilizer than None GLOBALGAP certified farmers. The showed that compliance to SCS and food safety and production standards enables snap bean smallholder farmers to directly access advanced value chains and ultimately receive higher prices for produce. We conclude by noting that the cost of implementing international food safety and production standards is still expensive to smallholder farmers especially in Sub-Saharan Africa.
\end{abstract}

Keywords: GLOBALG.A.P., food safety, production standards, conservation agriculture

\section{Introduction}

Globally food production system has been experiencing the transformation that greatly impacts on the global food supply value chains (Muller et al., 2017). One of the primary concern for changes in the production system is climate change and its impending threats to food and nutrition security. The effects will probably impact more in the developing countries that heavily depend on agriculture for livelihoods. For instance in Sub-Saharan Africa, agricultural production is the major employer in rural areas and also cushions against perennial food shortages (Stevenson et al., 2014). In the region, majority of the farmers are considered to own small parcels of land and are poor with low financial resources to cushion them against the adverse effects of climate change. The second concern to global food production is intensive agricultural production that advocates for excessive use of external inputs. This has been noted to increase the degradation of soil, water, and genetic resources over time. The increase in degradation of national resources not only pose a threat to global food security but 
destabilizes livelihoods of larger populations. A study by Tilman et al. (2011) noted that annually more than 10 million hectares of quality productive land is lost due to soil degradation process, this will affect more than 1.5 billion people who depend directly on the land.

Generally, the trends in the degradation of national resources are seen to be on the increase despite policies put in place to reduce the growing threats. In developing countries, the agricultural production system is facing an even greater magnitude of soil and water degradation in prime agrarian lands (Whitfield et al., 2015). In particular, smallholder farms are experiencing falling groundwater table, declining organic carbon and soil matter, intensive soil tillage, imbalance of soil nutrients, increase in the use of pesticides and herbicides. The factors are believed to have contributed to declining crop yields and the rising cost of production and high wages. While on the supply marketing chain, smallholder farmers are not only limited to access to advanced markets but are also experiencing low prices for agricultural commodities. Besides, farmers are facing pressure from consumer's increasing demand for higher food quality and safety standards (Annor et al., 2016).

To sustain food production, overcome modern agrarian challenges and ensure that producers have stable livelihoods, policies on the adoption of sustainable conservation standards have been promoted. Mainly sustainable conservational agricultural practices ensure that farmers observe i) surface-incorporation of crop residues ii) reduced tillage or soil disturbance iii) increase production of cover crops for both annual and perennial crops. The concept is aimed at enriching and promoting soil health by enhancing natural biological processes above and below the soil surface. Also, SCS emphasizes the need for preserving soil life system and allows for minimal use of farm chemicals, including fertilizer to replenish the soil. However, the chemicals inputs quantities used in Sustainable Conservation farming are lower in comparison to conventional farming (Milder et al., 2015).

Over the years' sustainable production standards have merged to be a promising response to challenges of the degradation of national resources. Most of the agricultural sustainable production standards mainly address issues related to environmental quality and biodiversity conservation (Bain et al., 2013). Globally agricultural sustainability conservation standards are applied in production of major crops such as cocoa (22\%), palm oil $(15 \%)$, and tea (12\%), coffee $(38 \%)$ sugar $(3 \%)$, soybeans $(2 \%)$, and other crops (Potts et al., 2014). Good Agricultural Practices (GLOBALGAP) production is one of the standards put in place to minimize the negative impact of agriculture on the environment while meeting consumer concerns of food safety. Specifically, GLOBALGAP aims to reduce the use of fertilizer, management of waste, minimize the use of pesticides and efficiently use of non-renewable resources. Also, the standards ensure farmers invest in worker's safety and traceability systems (Chan, 2016).

In Sub-Saharan Africa (SSA), land productivity and per capita food availability have been on the declining in comparison to other regions in the world. Declining soil fertility and high-cost inputs are mainly linked to low agricultural productivity in the region. The problem is more profound among poorly endowed smallholder farmers. Majority of the farmers lack knowledge, resources, and techniques to adopt sustainable agricultural production standards (Whitfield et al., 2014). Nevertheless, a considerable number of smallholder farmers have been supported and trained in sustainable conservation farming practices. Farmers targeting the export market have been forced by marketing agents to comply with agricultural conservation practices (Blaikie and 
Brookfield, 2015). On the contrary, large-scale farmers have resources to comply with the required food production standards easily. The concept of sustainable conservation standards is not only confined to improve environmental ecology and food safety but also archive acceptable profits sustained production level, and marketability of crops.

Studies in developing countries provide varied analysis of the increased competitiveness, in marketing and productivity in horticulture crops. While providing market linkage that has a positive impact on farmers' incomes, in most of the cases only farmers directly linked to advanced value chains tend to receive higher prices for their produce (Aasprong, 2013). Despite the associated benefits of being guaranteed market access, smallholder farmers are constantly under pressure to maintain sustainable production standards and sometime observe the set consumers food safety standards (Lockie et al., 2015). Prior studies have examined the returns on investments and social, economic benefits of horticultural crop production in developing economies (Henson et al., 2011). Conventionally, in Sub-Saharan Africa, farmers' profits are measured using financial gains in the form of gross margins. However, the techniques used don't show how exogenous factors such as farm characteristics, investments in sustainable conservation standards affected farms profit efficiencies levels.

In Asia, profit frontier function was used to estimate the profit efficiency of rice producers (Rahman, 2003; Chang et al., 2017). In computing profit efficiency, farmers can easily identify output level production, establish firms revenues and evaluate the benefits of investing in conservation agriculture (Abdulai and Huffman, 1998; Rahman, 2003). With this understanding, the objective of this study will examine variances in profit efficiency between certified GLOBALGAP farms and Non certified GLOBALGAP farms. Further, the study will examine utilization levels of sustainable conservation agriculture between certified GLOBALGAP farms and Non certified GLOBALGAP farms. The present study contributes to the debate on smallholder farmers producing efficiently in a perfectly competitive market while observing sustainable conservation agricultural production standards.

\section{Materials and Methods}

In Kenya, most of the snap beans are produced in the Central and Eastern regions. Snap beans are produced in well-drained silty loam to heavy clay soil that has $\mathrm{pH}$ range of between 6.5 to 7.5 . Also, the beans grow well in optimum temperatures ranging between $20^{\circ} \mathrm{C}$ and $25^{\circ} \mathrm{C}$. Snap beans do well in the altitude range of 1000 to 2100 meters. While the preferred rainfall for cultivation range is 900 to $1200 \mathrm{~mm}$ that is distributed throughout the year. Over the years there has been a decline in snap bean production that is mainly linked to i) erratic weather patterns, ii) declining soil fertility iii) use of banned pesticides such as dimethoate.

\section{Study area and sampling procedures}

The study employed multi-stage sampling technique to select 429 respondents who participated in the study. The first stage was purposively selecting major snap beans producing counties (Kirinyaga, Murang'a and Embu) in Kenya (Figure 1). A sampling frame of 3200 snap beans smallholder farmers from the three regions was obtained from ministry of Agriculture office. Using households sampling methodology formula 429 farmers were selected using simple random sampling procedure to participate in the 
study. The data used in the study was collected between June 2016 and September 2016 in three major snap beans producing Counties in Kenya.

Data was collected through household surveys involving a face-to-face interview; this allowed interviewers to make a clarification on questions and to probe the respondents for accurate answers. The questionnaire was administered in local languages, to farmers who were farming snap beans in the last six years. The enumerators only interviewed respondents who were above 18 years and made most farming decision in the household (household head or spouse, farm employee). The identified farmers answered a detailed questionnaire on snap bean farming management, production, harvesting, and marketing of the beans. Also, farmers were presented with probing questions on perceptions and knowledge awareness of sustainable conservation agriculture and Global Good Agricultural Practices Good Agricultural Practices (GLOBALGAP) (The respondents provided information on household characteristics, land size, social capital, as well as non-income indicators.

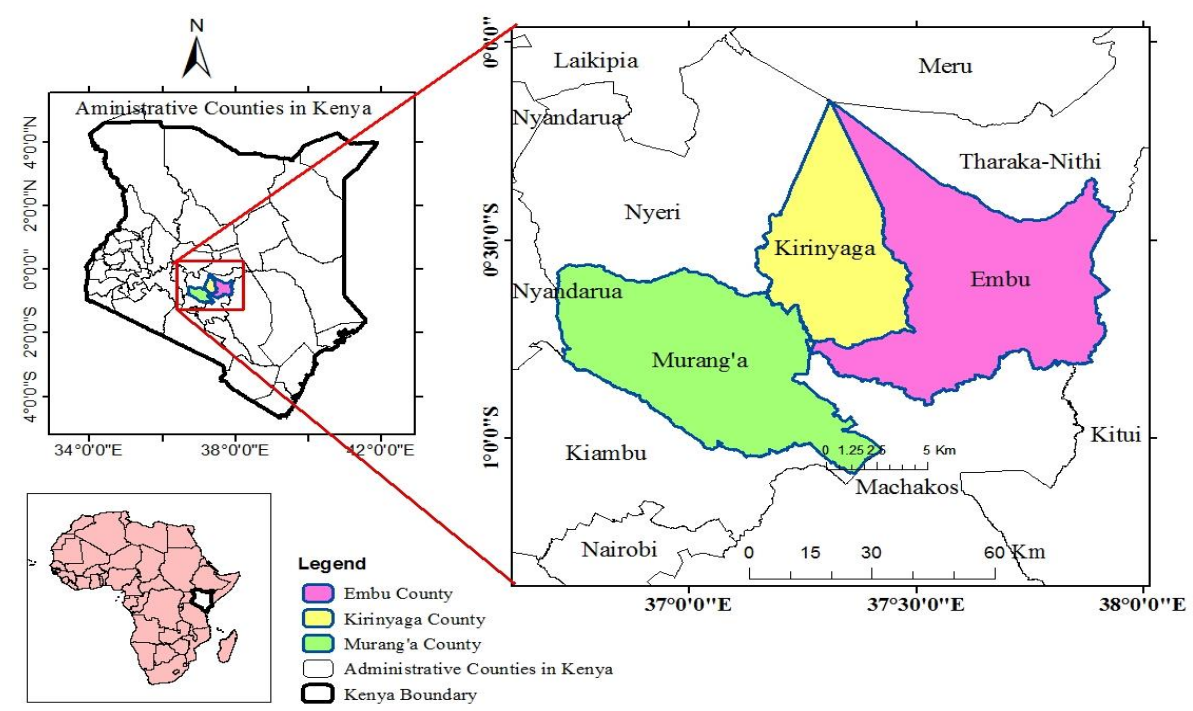

Figure 1. Map of the study area

\section{Empirical analysis of profit efficiency}

Traditionally, the farm production process has been measured using production function while efficiency has been estimated using deterministic or parametric approaches (Aigner et al., 1977; Van den Broeck et al., 1994). However, the profit frontier theory assumes that producers are always willing to maximize their profits, but not all are fully technically efficient. In a perfect competitive market, profits are assumed to be zero in the long run, producers operating at a negative profit are bound to exit the industry (Kumbhakar et al., 2015). Equally, if the profits are positive more will be attracted to in the industry. In the long run this increases market competition and drive profits to zero. Theoretically, firms are also seen to have short and long runs sequence of operating within profits as well as negatives. Thus profit efficiency is used in the present study to compare snap bean profit frontier function for certified GLOBALGAP farms and Non-GLOBALGAP farms in a perfectly competitive market.

Past studies in Africa and Asia have applied stochastic profit frontier models by considering estimation of the cost function (Ali and Flinn, 1989; Abdulai and Huffman, 
1998; Chang et al., 2017). However, there is the assumption that cost function ignores the variances of profits and cost. In addition, the profit function takes into account that commodity prices are not homogeneous for all producers. The efficiency estimated by profit function can be used to evaluate management efficiency of producing highquality products. In this study, we use one-step estimation and a Translog profit function. The efficiency determinant factors are included as the inefficiency term and estimated with the selected estimation function. Rahman (2003) argues that one-step estimation solves the statistical problem of consistency. The profit frontier function can simply be expressed as;

$$
1 \mathrm{n} \Pi_{i} 1 n \pi_{i}=\alpha_{0}+\sum_{j=1}^{j} \alpha_{j} \ln x_{i j}+v_{i}-u_{i}
$$

where $\Pi_{i}$ is the profit of the $i^{\text {th }}$ farm, xi's are the cost of different production inputs such, seed, water, labor (hired and own) and fertilizers (manure and chemical fertilizers). The error component $v_{i}$ is assumed to be random variables identical independently distributed (iii) $N\left(0, \sigma_{v}^{2}\right)$ that contains statistical noise. $u_{i}$ denotes the Non-negative random accounting for profit inefficiency expected to be truncated at zero $N\left(0, \sigma_{v}^{2}\right)$ distribution. Technical efficiency enables us to know variables that affect farm inefficiency. The equation is written as;

$$
u_{i}=\delta_{0}+\sum_{k=1}^{k} \delta_{d} z_{i k}+\omega_{i}
$$

Input costs and farm characteristics are assumed to influence the profit efficiency of both GLOBALGAP certified, and None GLOBALGAP certified farms, in the equation ${ }^{Z i}$ are the explanatory variables that explain inefficiency. The list of inefficiency variables used in different models includes farmer's characteristics, distance to market, number of extension contacts, subsidy support, and farmer's group membership. Inefficiency is denoted by $\mathrm{E}[\exp (-\mathrm{u}) \mid v]$, and is a truncated normal distribution as outlined by (Battese and Coelli, 1995; Kumbhakar et al., 2015).

\section{Results and discussion}

\section{Socioeconomic characteristics of respondents}

Table 1 presented descriptive statistics for the survey; in general farmers in the study allocated an average of 1.2 hectares of land to snap bean production. Also we noted that only $58 \%$ of the farmers produced snap beans with GLOBALGAP certification. Despite the fact that snap bean production venture require smallholder farmers to have skills to comply with the Good Agricultural Practices standards, only 40 percent received regular extension visit. Further results showed that only 47 percent of the farmers received subsidy support from marketers, saving and credit co-operatives groups, Governmental and Nongovernmental organizations. However, 24 percent of the farmers accessed credit from formal banks to invest in the snap bean production venture in the year of the survey.

Table 2 presented the difference in characteristics of GLOBALGAP certified and Non-certified farmers. The analysis revealed that farmers who had GLOBALGAP certification were older and had more years in education than the None certified 
farmers. Farmers with fully GLOBALGAP certification owned 1.087 hectors of snap beans farm size while None GLOBALGAP farmers owned 1.433. Generally, farmers with GLOBALGAP certification incurred $176.29 \$$ on the cost of inputs such as seedlings, fertilizers, and pesticides. Also, they had additional input cost on soil/water testing and preservation, hygiene and sanitation units, packaging crates and traceability systems. While the None certified GLOBALGAP farmers only incurred input cost of $\$ 132.68$ mainly related to seedlings, fertilizers, and pesticides. Despite farmers with GLOBALGAP certification incurring high cost if inputs, they also received higher returns of $\$ 1008.27$ compared to $\$ 307.32$ received by None GLOBALGAP certified farmers. Further, we noted that none GLOBALGAP farmers incurred more cost in land preparation than GLOBALGAP certified farmers.

Table 1. Definition of variables (Source: Research findings)

\begin{tabular}{c|c|c|c}
\hline Variables & Description & Mean & St.Dev \\
\hline GAP certification & 1 if a farmer has GLOBALGAP certificate otherwise 0 & 0.580 & 0.494 \\
Age & Age of the Household Head in years & 44.64 & 12.83 \\
Education & Number of years of schooling & 9.669 & 2.578 \\
Farm size & Total farm size under snap beans in hectares & 1.232 & 1.089 \\
Co-operative membership & 1 of farmers belong to farmers groups otherwise 0 & 0.765 & 0.424 \\
Extension contact & 1 if farmer visited extension services on Snap bean & 0.408 & 0.492 \\
& production other wise 0 & & \\
Access to credit & 1 if farmer received a loan to finance snap bean venture & 0.242 & 0.429 \\
Under contract farming & otherwise 0 & 0.540 & 0.497 \\
Years of GLOBALGAP & 1 if farmer is under contract farming other wise 0 & 2.840 & 1.802 \\
certification & Years of GLOBALGAP has certification & 0.471 & 0.499 \\
Farmers subsidy support & 1 farmer received support from NGO otherwise 0 \\
Distance to market & Distance to collection center market in kilometers & 4.379 & 3.345 \\
\hline
\end{tabular}

Table 2. Differences in characteristics between GLOBALGAP compliance and Noncompliance farmers (Source: Research findings)

\begin{tabular}{|c|c|c|c|c|c|c|}
\hline & \multicolumn{2}{|c|}{$\begin{array}{c}\begin{array}{c}\text { GLOBALGAP certified } \\
n=249\end{array} \\
\end{array}$} & \multicolumn{2}{|c|}{$\begin{array}{c}\text { None-GLOBALGAP } \\
n=180 \\
\end{array}$} & \multicolumn{2}{|c|}{ T-test } \\
\hline & Mean & (Sd) & Mean & (Std) & $T$ & $\mathbf{P}$ \\
\hline Age Years & 46.48 & $(12.96)$ & 42.106 & $(12.24)$ & $-3.534 * * *$ & 0.002 \\
\hline Education Years & 9.751 & $(2.397)$ & 9.556 & $(2.813)$ & 0.774 & 0.439 \\
\hline Land size (ha) & 1.087 & $(1.002)$ & 1.433 & $(1.172)$ & 3.288 & 0.999 \\
\hline $\begin{array}{l}\text { Quantity snap bean produced } \\
\text { Kgs }\end{array}$ & 1486 & $(2934.9)$ & 848.0 & $(1681.4)$ & $-2.620 * * *$ & 0.004 \\
\hline Ave. returns in $\$$ & 1008.27 & $(1.534)$ & 307.32 & $(30151)$ & $-4.546 * * *$ & 0.008 \\
\hline Ave. Input cost in \$ & 176.29 & $(2721)$ & 132.68 & $(23529)$ & 1.613 & -1.910 \\
\hline Land preparation Cost in $\$$ & 24.87 & $(4169)$ & 21.85 & $(2827)$ & -0.841 & 0.200 \\
\hline
\end{tabular}

The last two column gives the $t$ test statistics for equal means in the GLOBALGAP Certified and NoneGLOBALGAP group. $* * * \mathrm{p}<0.01, * * \mathrm{p}<0.05, * \mathrm{p}<0.1$

\section{Compliance to sustainable conservation standards}

Figure 2, presented comparative analysis on the levels of compliance to sustainable conservation standards between GLOBALGAP certified and None certified farmers. Generally, the results indicated that more than 73 percent of the farmers applied water conservation techniques in their farms. 
Further results revealed that 45 percent of the GLOBALGAP certified farmers used organic fertilizer in comparison, only 17 percent of the None certified farmers. We noted that GLOBALGAP certified farmers were less likely to apply pesticides, herbicides, and fertilizer than None GLOBALGAP certified farmers. The results indicated that only 20 percent of None GLOBALGAP certified farmers applied soil conservation technique minimum tillage while 65.9 percent of the GLOBALGAP certified applied the technique.

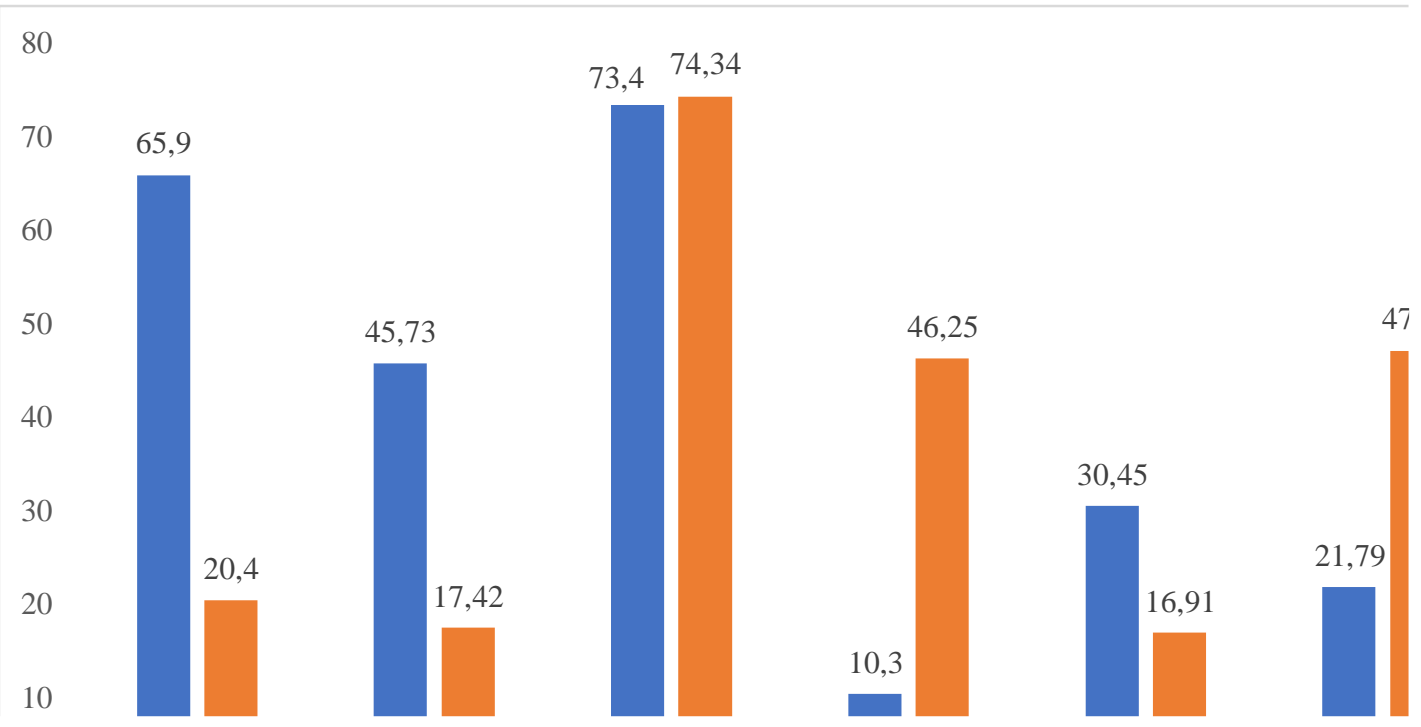

Figure 2. Compliance to Sustainable Conservation Standards by Snap bean farmers

\section{Profit efficiency estimation}

The maximum likelihood estimates of profit frontier function are presented in Table 3. The dependent variable is snap bean profits from the output of the whole year. The coefficient estimates parameter follows the normal profit function based on the assumption of a competitive market. The study results revealed that investing and complying to GLOBALGAP Ln(GAPC) farming standards negatively and significantly impacted profits of non- certified farmers. Also, General Input Cost (Ln GIC) negatively impact on none GLOBALGAP certified farms profits by $2.2 \%$. Further results showed that land size would positively and significantly influence on profit efficiency of GLOBALGAP certified farms. While General Input Cost (Ln GIC) negatively impact on profits GLOBALGAP certified farms. Regarding characteristics that determine profit inefficiency, the results showed that farmers age, education years, years of GAP farming, distance to Market, GLOBAL GAP application in the farm, and contract farming would significantly influence on inefficiency for GLOBALGAP certified farms. While farmers age experience and distance to market determined on profit efficiency of Non- GLOBALG.A.P Certified farms

Table 4 shows the decile frequency distribution between GLOBALGAP certified, and non- GLOBALGAP certified farms. In general, the results revealed that the average measure of profit efficiency for GLOBALGAP certified farmers was 0.625 percent. This, implied that GLOBALGAP certified farmers got an average of about 62.5 percent of maximum profit potential. 
Table 3. Frontier Profit Function (Source: Research findings)

\begin{tabular}{|c|c|c|c|c|c|}
\hline & \multirow[t]{2}{*}{ Parameters } & \multicolumn{2}{|c|}{$\begin{array}{l}\text { GLOBALG.A.P } \\
\text { Certified }\end{array}$} & \multicolumn{2}{|c|}{$\begin{array}{c}\text { Non- GLOBALG.A.P } \\
\text { Certified }\end{array}$} \\
\hline & & Coef & Std-err & Coef & Std-err \\
\hline $\operatorname{Ln}(\mathrm{GIC})$ & $\overline{\beta_{1}}$ & 0.005 & 0.021 & -0.022 & 0.060 \\
\hline $\operatorname{Ln}(\mathrm{GAP})$ & $\beta_{2}$ & -0.001 & 0.006 & $-0.099^{* *}$ & 0.043 \\
\hline Ln (Landsize) & $\beta_{3}$ & $1.002^{* * * *}$ & 0.017 & 0.008 & 0.002 \\
\hline $\operatorname{Ln}(\mathrm{GIC}) \times \operatorname{Ln}(\mathrm{GAP})$ & $\beta_{4}$ & 0.001 & 0.008 & -0.001 & 0.001 \\
\hline $\operatorname{Ln}(\mathrm{GIC}) \times \operatorname{Ln}($ Landsize $)$ & $\beta_{5}$ & -0.002 & 0.003 & 0.035 & 0.004 \\
\hline $\operatorname{Ln}(\mathrm{GAP}) \times \operatorname{Ln}($ Landsize $)$ & $\beta_{6}$ & 0.001 & 0.014 & $0.027^{* * * *}$ & 0.003 \\
\hline $\mathrm{Ln}(\mathrm{GIC}) \times \mathrm{Ln}(\mathrm{GIC})$ & $\beta_{7}$ & 0.0015 & 0.011 & $0.568^{* * * *}$ & 0.201 \\
\hline $\operatorname{Ln}(\mathrm{GAP}) \times \operatorname{Ln}(\mathrm{GAP})$ & $\beta_{g}$ & -2.800 & 4.400 & $0.006^{* * *}$ & 0.342 \\
\hline $\operatorname{Ln}(\mathrm{LS}) \times \operatorname{Ln}(\mathrm{LS})$ & $\beta_{7}$ & $0.033^{* * *}$ & 0.012 & $0.640^{* * *}$ & 0.052 \\
\hline cons & & -.4104 & 0.113 & -14.14 & 20.09 \\
\hline \multicolumn{6}{|l|}{ Determinants of efficiencies } \\
\hline Ln(farmer's age) & $\delta_{1}$ & $0.029^{* * * *}$ & 0.005 & -0.005 & 0.012 \\
\hline Ln(HH Edu years) & $\delta_{2}$ & $0.051^{* * * *}$ & 0.008 & 0.007 & 0.011 \\
\hline Ln (Years of GAP farming) & $\delta_{3}$ & $0.010_{* * *}$ & 0.002 & -0.001 & 0.004 \\
\hline Ln(Distance to Market) & $\delta_{4}$ & $0.005^{* *}$ & 0.002 & -0.007 & 0.002 \\
\hline $\begin{array}{l}\text { In (extent of GLOBAL GAP } \\
\text { application in farm) }\end{array}$ & $\delta_{5}$ & $0.025^{* * *}$ & 0.004 & -0.004 & 0.003 \\
\hline Dummy for GAP extension & $D_{1}$ & 0.004 & 0.003 & -0.003 & 0.004 \\
\hline Dummy if buyer is GAP certified & $D_{2}$ & 0.005 & 0.003 & 0.070 & 0.007 \\
\hline $\begin{array}{l}\text { Dummy for membership to } \\
\text { GLOBAL GAP farmers group }\end{array}$ & $D_{3}$ & 0.022 & 0.004 & 0.002 & 0.005 \\
\hline $\begin{array}{c}\text { Dummy for GLOBAL GAP subsidy } \\
\text { support }\end{array}$ & $D_{4}$ & 0.006 & 0.035 & 0.073 & 0.050 \\
\hline Dummy for contract farming & $D_{5}$ & $0.007^{* * *}$ & 0.038 & -0.053 & 0.005 \\
\hline Usigma_cons & & $-14.38^{*}$ & 8.267 & -14.14 & 20.09 \\
\hline$\underset{\lambda}{\operatorname{Vsigma}}{ }^{-c o n s}$ & & $\begin{array}{l}0.026 \\
0.028\end{array}$ & -7.291 & $\begin{array}{c}-7.092 \\
0.029\end{array}$ & 0.112 \\
\hline
\end{tabular}

Note: ${ }^{* * *, * * * *}$ Significant at 1, 5, 10, percent levels respectively Abbreviations: Log (Ln), General Input Cost (GIC), Good Agricultural Cost(GAPC), Land Size (LS)

Table 4. Deciles Frequency Distribution of Profit Efficiencies of Snap bean Farmers (Source: Research findings)

\begin{tabular}{c|c|c|c|c}
\hline \multirow{2}{*}{ Efficiency level } & \multicolumn{2}{|c|}{ GLOBALGAP certified farms } & \multicolumn{2}{c}{ Non- GLOBALGAP farms } \\
\cline { 2 - 5 } & Frequency & Relative Efficiency \% & Frequency & Relative Efficiency \% \\
\hline$<0.010$ & 4 & 1.61 & 59 & 32.78 \\
$0.21-0.40$ & 37 & 14.86 & 50 & 27.78 \\
$0.41-60$ & 48 & 19.28 & 21 & 11.67 \\
$0.61-0.80$ & 73 & 29.32 & 22 & 12.22 \\
$0.81-1.00$ & 87 & 34.94 & 28 & 15.56 \\
\hline Total & $\mathbf{2 4 9}$ & $\mathbf{1 0 0}$ & 0.017 & \\
Minimum & 0.030 & & 0.876 & \\
Maximum & 0.999 & & 0.409 & \\
Mean & 0.625 & & 0.313 & \\
Std Deviation & 0.237 & & $\mathbf{1 0 0}$ \\
\hline
\end{tabular}

This was gained due to production efficiency while the remaining shortfall of the discrepancy between observed profit and the frontier profit can be attributed to both technical and allocative inefficiencies as had earlier been confirmed by the likelihood ratio test. Further results showed non-GLOBALGAP farmers got an average of about 40.9 percent of maximum potential profit from snap bean venture. 


\section{Discussion}

The main objective of this study was to examine the levels of compliance with sustainable conservation standards and estimate the profit efficiency of snap bean production between GLOBALGAP and Non-GLOBALGAP. The data was based on 429 smallholder farmers in Kenya. The comparative analysis on levels of utilization of sustainable conservation standards revealed that GLOBALGAP certified farmers were likely to apply soil conservation technique minimum tillage than Non-GLOBALGAP farms. Presently, extension messages in developing countries emphasize the use of reduced tillage. However, there, are indications that farmers are slow in adopting such practices (Luangduangsitthideth et al., 2018). Soil fertility experts recommend integration of organic matter from livestock and post-harvest crop waste to raise soil carbon levels. The study showed that the application of organic manure was less than 50 percent for both GLOBALGAP certified and Non- certified farmers. Previous studies reported that organic utilization of manure enhanced soil structure, improved soil carbon components while availing nutrients and mineral fertilizers to plants (Boström et al., 2015). We noted that low levels of inorganic fertilizer use by GLOBALGAP certified farms than for Non-certified farmers. Whitfield et al. (2015) reported that organic manure use improved the efficiency of fertilizer use by farmers.

The results of the study also indicated that the profit efficiency of GLOBALGAP certified farms was significantly higher than that Non-GLOBALGAP certified farms. The international food safety compliance literature showed that smallholder farmers in developing countries were locked out of the export market for non-compliance with sustainable conservation standards. In most of the cases, farmers were unable to meet requirements on environmental management, traceability standards, product safety, and the health safety of the workers (Kleemann et al., 2014). Thus, compliance with sustainable conservation standards such as GLOBALGAP would be prohibitive to farmers with low capital investment, a factor that affected the snap bean profit margins. Similarly, Lockie et al. (2013) reported that the use of safer pesticides required farmers to incur a higher cost of pest and disease management. Also, the cost of implementing GLOBALG.A.P certification could cost smallholder farmers up to 65 percent of the production cost (Muriithi et al., 2011). According to (Bain et al., 2013) compliance with sustainable production standards necessitated an increase in the cost of operation hence affecting the revenues.

The present study pointed out that farmer's group created inefficiencies for nonGLOBALGAP and GLOBALG.A.P Certified farms. However, Fernandez-Stark et al. (2011) study that farmers co-operatives are likely to get better returns when dealing directly with marketing companies or supermarket chains than middlemen. Also, collective action by farmer's organizations increased credit acquisition chances, the ability to negotiate prices, and market assurance. Supporting farmers with inputs, credit, and extension services resulted in reduced profit inefficiency, especially for GLOBALG.A.P certified farmers. The support services would help farmers to observe sustainable conservation standards required by buyers. Also, Aasprong (2013) notes that agricultural extension support system facilitated dissemination of suitable technologies to farmers reduced the inefficiency in Madagascar. 


\section{Conclusion}

In conclusion, we noted that food production and certification standards such as GLOBALG.A.P significantly facilitate smallholder farmers to observe sustainable conservation practices. In particular, the standards help reduction in pesticide use, inorganic fertilizer use, minimum soil disturbance. However, the governments and other stakeholders in Sub-Saharan Africa have to mobilize and create awareness on the benefits of sustainable conservation standards. Also, there is a need to have a policy shift and address the perception that inorganic fertilizer is the panacea for smallholder productivity.

We also noted that smallholder snap bean farmers need to increase profit efficiency marginally. Much of the policy emphasis must be directed towards increasing compliance to sustainable conservation standards not only for the export target market but also local Kenyan market. However, high rejection rate resulting from Noncompliance sustainable conservation standards will likely lead farmers to produce for local market where they invest less and still get marginal profits from the snap beans. While compliance to sustainable conservation standards such as GLOBALG.A.P standards guarantees a ready market for the snap bean, there is need to scale up subsidies relating to sustainable conservation standards certification and compliance for snap bean venture to be more profit efficient. This will enhance smallholder's snap bean farmers in Kenya to efficiently produce and maintain competitiveness in the global market that is becoming more dynamic, especially with regards to environmental and food safety standards.

Acknowledgements. This paper was made possible through financial support of East Africa's Agricultural Policy and its impact on Sino-East Africa Agricultural Cooperation project and Priority Academic Program Development of Jiangsu Higher Education (PAPD). Grant no KYGB201802.

\section{REFERENCES}

[1] Aasprong, H. (2013): Entangled standardizing networks: the case of GLOBALGAP and Fairtrade in St Vincent's banana industry. - Int. J. Sociol. Agric. Food 20:91-108.

[2] Abdulai, A., Huffman, W. E. (1998): An examination of profit inefficiency of rice farmers in Northern Ghana. - Iowa State University, Department of Economics, Staff General Research Paper.

[3] Aigner, D., Lovell, C. K., Schmidt, P. (1977): Formulation and estimation of stochastic frontier production function models. - Journal of econometrics 6: 21-37.

[4] Ali, M., Flinn, J. C. (1989): Profit efficiency among Basmati rice producers in Pakistan Punjab. - American Journal of Agricultural Economics 71: 303-310.

[5] Aloui, O., Kenny, L. (2005): The cost of compliance with SPS standards for Moroccan exports: a case study. - World Bank Agriculture and Rural Development Discussion Paper. World Bank, Washington DC.

[6] Annor, B. P., Mensah-Bonsu, A., Jatoe, J. B. D. (2016): Compliance with GLOBALGAP standards among smallholder pineapple farmers in Akuapem-South, Ghana. - Journal of Agribusiness in Developing and Emerging Economies 6: 21-38.

[7] Asfaw, S., Mithöfer, D., Waibel, H. (2010): Agrifood supply chain, private-sector standards, and farmers' health: evidence from Kenya. - Agricultural Economics 41: 251263. 
[8] Bain, C., Ransom, E., Higgins, V. (2013): Private agri-food standards: Contestation, hybridity and the politics of standards. - International Journal of Sociology of Agriculture and Food 20: 1.

[9] Battese, G. E., Coelli, T. J. (1995): A model for technical inefficiency effects in a stochastic frontier production function for panel data. - Empirical economics 20: 325332.

[10] Blaikie, P., Brookfield, H. (2015): Land degradation and society. - Routledge.

[11] Boström, M., Jönsson, A. M., Lockie, S., Mol, A. P., Oosterveer, P. (2015): Sustainable and responsible supply chain governance: challenges and opportunities. - Journal of Cleaner Production 107: 1-7.

[12] Chan, K. (2016): Manual on good agricultural practices (GAP). - Asian Productivity Organization (APO).

[13] Chandra, A., Idrisova, A. (2011): Convention on Biological Diversity: a review of national challenges and opportunities for implementation. - Biodiversity and Conservation 20: 3295-3316.

[14] Chang, T., Takahashi, D., Yang, C.-K. (2017): Profit efficiency analysis of rice production in Taiwan. - China Agricultural Economic Review 9: 32-47.

[15] Delgado, J. A., Groffman, P. M., Nearing, M. A., Goddard, T., Reicosky, D., Lal, R., Kitchen, N. R., Rice, C. W., Towery, D., Salon, P. (2011): Conservation practices to mitigate and adapt to climate change. - Journal of soil and water conservation 66: 118A129A.

[16] Fernandez-Stark, K., Bamber, P., Gereffi, G. (2011): The Fruit and Vegetable Global Value Chain: Workforce Development and Economic Upgrading. - Durham: Center for Globalization. Governance and Competitiveness.

[17] Giller, K. E., Corbeels, M., Nyamangara, J., Triomphe, B., Affholder, F., Scopel, E., Tittonell, P. (2011): A research agenda to explore the role of conservation agriculture in African smallholder farming systems. - Field crops research 124: 468-472.

[18] Henson, S., Masakure, O., Cranfield, J. (2011): Do fresh produce exporters in subSaharan Africa benefit from GlobalGAP certification? - World Development 39: 375386.

[19] Humphrey, J. (2008): Private standards, small farmers and donor policy: EUREPGAP in Kenya. - Working paper series, 308. Brighton: IDS.

[20] Joshi, P. (2011): Conservation agriculture: an overview. - Indian Journal of Agricultural Economics 66: 53.

[21] Kleemann, L., Abdulai, A., Buss, M. (2014): Certification and access to export markets: Adoption and return on investment of organic-certified pineapple farming in Ghana. World Development 64: 79-92.

[22] Kumbhakar, S. C., Wang, H., Horncastle, A. P. (2015): A practitioner's guide to stochastic frontier analysis using Stata. - Cambridge University Press.

[23] Lockie, S., McNaughton, A., Thompson, L.-J., Tennent, R. (2013): Private food standards as responsive regulation: the role of national legislation in the implementation and evolution of GLOBALG. AP. - International Journal of Sociology of Agriculture \& Food 20.

[24] Lockie, S., Travero, J., Tennent, R. (2015): Private food standards, regulatory gaps and plantation agriculture: social and environmental (ir) responsibility in the Philippine export banana industry. - Journal of Cleaner Production 107: 122-129.

[25] Luangduangsitthideth, O., Limnirankul, B., Kramol, P. (2018). Farmers' knowledge and perceptions of sustainable soil conservation practices in Paklay district, Sayabouly province, Lao PDR. - Kasetsart Journal of Social Sciences, available at: https://doi.org/10.1016/j.kjss.2018.07.006.

[26] Milder, J. C., Arbuthnot, M., Blackman, A., Brooks, S. E., Giovannucci, D., Gross, L., Kennedy, E. T., Komives, K., Lambin, E. F., Lee, A. (2015): An agenda for assessing and 
improving conservation impacts of sustainability standards in tropical agriculture. Conservation biology 29: 309-320.

[27] Minten, B., Randrianarison, L., Swinnen, J. (2007): Spillovers from high-value agriculture for exports on land use in developing countries: evidence from Madagascar. Agricultural Economics 37: 265-275.

[28] Mugunzwe, H., Tshirley, D. (2006): Understanding Zambia's Domestic Value Chains for Fresh Fruits and Vegetables. Food Security Research Project, Zambia. http://ageconsearch. umn. edu/bitstream/54621/2/ps17. pdf.

[29] Muller, A., Ferré, M., Engel, S., Gattinger, A., Holzkamper, A., Huber, R., Müller, M., Six, J. (2017): Can soil-less crop production be a sustainable option for soil conservation and future agriculture? - Land Use Policy 69: 102-105.

[30] Muriithi, B. W., Mburu, J., Ngigi, M. (2011): Constraints and determinants of compliance with EurepGap standards: a case of smallholder french bean exporters in Kirinyaga district, Kenya. - Agribusiness 27: 193-204.

[31] Okello, J. J., Swinton, S. M. (2010): From circle of poison to circle of virtue: pesticides, export standards and Kenya's green bean farmers. - Journal of agricultural economics 61: 209-224.

[32] Potts, J., Lynch, M., Wilkings, A., Huppé, G. A., Cunningham, M., Voora, V. A. (2014): The state of sustainability initiatives review 2014: Standards and the green economy. International Institute for Sustainable Development Winnipeg, MB.

[33] Rahman, S. (2003): Profit efficiency among Bangladeshi rice farmers. - Food policy 28: 487-503.

[34] Saei, M., Mohammadi, H., Ziaee, S., Barkhordari, S. (2018): Economic effect of climate alteration on grain production in Iran. - Applied Ecology and Environmental Research 16: 6691-6707.

[35] Stevenson, J. R., Serraj, R., Cassman, K. G. (2014): Evaluating conservation agriculture for small-scale farmers in Sub-Saharan Africa and South Asia. - Elsevier.

[36] Tilman, D., Balzer, C., Hill, J., Befort, B. L. (2011): Global food demand and the sustainable intensification of agriculture. - Proceedings of the National Academy of Sciences 108: 20260-20264.

[37] Van den Broeck, J., Koop, G., Osiewalski, J., Steel, M. F. (1994): Stochastic frontier models: A Bayesian perspective. - Journal of Econometrics 61: 273-303.

[38] Van der Meer, C. (2006): Exclusion of small-scale farmers from coordinated supply chains. - Agro-food Chains and Networks for Development, Amsterdam 209-218.

[39] Whitfield, S., Dougill, A., Wood, B., Chinseu, E., Mkwambisi, D. (2014): Conservation Agriculture in Malawi: Networks, Knowledge Gaps and Research Planning. - Report on the National Conservation Agriculture Research Planning Workshop, Lilongwe, 6th May, 2014.

[40] Whitfield, S., Dougill, A. J., Dyer, J. C., Kalaba, F. K., Leventon, J., Stringer, L. C. (2015): Critical reflection on knowledge and narratives of conservation agriculture. Geoforum 60: 133-142.

[41] Wysokinski, M., Golasa, P., Bienkowska, W. (2012): The importance of GLOBAL GAP for food safety in the supply chain. - Logistyka 6. 